\title{
Phytochemical Screening of Leaf Extracts of Azadirachta indica and Psidium guajava
}

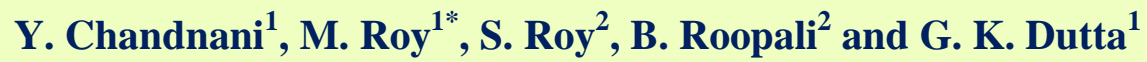 \\ ${ }^{1}$ Veterinary Physiology and Biochemistry Department, ${ }^{2}$ Veterinary Medicine College \\ of Veterinary Science \& A.H., Anjora, Durg (Chhattisgarh), India \\ *Corresponding author
}

A B S T R A C T

\begin{tabular}{l} 
K e y w o r d s \\
Phytochemical, \\
Extract, Leaves, \\
Antioxidants, \\
Therapeutic \\
Article Info \\
\hline $\begin{array}{l}\text { Accepted: } \\
\text { 20 August } 2020 \\
\text { Available Online: } \\
\text { 10 September } 2020\end{array}$ \\
\hline
\end{tabular}

\section{Introduction}

Medical Plant constitutes therapeutic effect in alleviating ailments in humans and animals. Almost $80 \%$ of the world populations are fully dependant on herbal medicines because of awareness about side effects and toxicity accumulation in organs (Bukata et al., 2016). The herbal medicines today symbolize safe and surety in contrast to the synthetics that are regarded as unsafe to human and environment. The World Health Organization (WHO) has outlined herbal medicine as culminated labelled medicinal products that incorporate lively ingredients as aerial or underground accessories of plants or other plant fabric (Romila et al., 2010).

Azadirachta indica commonly called as Neem, has become important in the global context today because it offers answers to the major concerns facing mankind. It is a fastgrowing evergreen popular tree found commonly in India, Africa and America. Neem is most important medicinal plant that have been used as a general folk medicine, and more recently, its constituents have been purified and found to possess greater 
antioxidant, hepatoprotective, antimicrobial, and anticancerous activities (Harway et al., 2013). Moreover, its constituents also show therapeutic implications in the modulation of cell signaling pathways involved in the management of cancer. The Azadirachta indica leaves are greatly used among the quite a lot of tribes of India to remedy cuts, wounds and different minor dermis illnesses (Padal et al., 2013).

Psidium guajava (common name-guava) is well known tropic tree belongs to phylum Magnoliophyta, class Magnoliopsida and Myrtaceae family has been extensive use in folk medicine (Nasser \& Naeem, 2018) Different parts of the plant can be used in the treatment of diseases such as wounds, lesions, ulcers, diarrhea, cholera, hypertension, obesity and the control of diabetes mellitus. Guava leaves have been used to treat cough and pulmonary diseases, diarrhea, malaria and dysentery, sore throats, vomiting and menstrual complications. Tender leaves are chewed for bleeding gum and bad breath. Natural products play a consequential role in the field of new drugs research and development because of their long history of safety profile, availability and reasonable cheapness. They also represented the most productive source of lead compounds, which are involved in the optimization strategies of drug design. Phytochemicals produced by all plants repositories which has some medicinal uses. During the past few decades, the pharmaceutical industry conducted research on the phytochemical agents to discover potent drug against different ailment (Arika et al., 2015). The beneficial roles of phytochemicals are their less toxicity, low cost, easy availability and biological significance such as antioxidant potential, antimicrobial effects, stimulation of the immune system and many more (Ramadass and Subramanian, 2018).
The aim of this study was to determine the bioactive compounds present in the Psidium guajava (Linn) and Azadirachta indica leaves extract with the aid of quantitative techniques, which may provide an insight in its use in tradition medicine.

\section{Materials and Methods}

\section{Collection of Plant material}

Fresh leaves of Azadirachta indica was procured from district Durg of Chhattisgarh state and nearby areas. The leaves of Psidium guajava and Azadhiracta indica were washed under running tap water and dust was removed from the leaves. The leaves were dried at shaded places for 15 days and coarsely powdered.

\section{Preparation of extract}

Five gram of grinded powder had been percolated with one $200 \mathrm{ml}$ of solvent (Aqueous, Aquamethanol and Acetone) for extraction and kept at soxhlet $150^{\circ} \mathrm{C}$ temperature for 36 hours. The extracts were filtered before drying using Whatman filter paper no.1 on a Buchner funnel and the solvent was removed by vacuum distillation in a rotary evaporator at $40^{\circ} \mathrm{C}$; the extracts were placed in pre-weighed flasks before drying. Finally the extracts of A.indica and Psidium guajava leaves were used for the phytochemical screening. Qualitative Phytochemical Screening

Extracts were tested for the presence of alkaloids as per method given by Evans (1997) and Wagner (1993).

Test for Alkaloids: $2 \mathrm{ml}$ of each extract was mixed with $0.2 \mathrm{ml}$ of diluted HCL solution. Then $1 \mathrm{ml}$ of Wagner's reagent was added (1.27 $\mathrm{g}$ of iodine and $2 \mathrm{~g}$ potassium iodide along with $100 \mathrm{ml}$ distilled water). Positive 
test is confirmed by reddish brown precipitate.

Test for Tannins: $2 \mathrm{ml}$ of each extract mixed with few drops of 5\% ferric chloride solution. Formation blue colour indicates the presence of tannins.

Test for Saponins: $5 \mathrm{ml}$ of each extract shaken vigorously with $5 \mathrm{ml}$ of distilled water in a test tube and warmed. Formation of stable foam indicated the test as positive.

Test for Flavonoids: $1 \mathrm{ml}$ of each extract mixed with $1 \mathrm{ml}$ of $10 \%$ lead acetate solution. Formation of yellow precipitate indicated the test as positive.

Test for Glycosides: $2 \mathrm{ml}$ of each extract was dissolved in glacial acetic acid and 5\% ferric chloride solution was added. The contents were heated and cooled then transferred to a test tube containing $2 \mathrm{ml}$ concentrated sulphuric acid. Pale green colour appears in upper layer that indicates the presence of glycoside.

\section{Results and Discussion}

The pharmaceutical importance and medicinal values of the medicinal plants are in the bioactive phytochemical metabolites that produce specific physiological action. The most important bioactive plant constituents are saponins, flavonoids, and alkaloid (Oyenihi and Smith, 2019). The Phytochemical test was conducted to determine the presence of active chemical constituents in Azadirachta indica and Psidium guajava leaves extracts prepared in different solvents. The phytochemical analysis of extracts, aqueous, aqueous methanolic and acetone was presented in Showed in table 1 .

Table.1 Qualitative phytochemical analysis of dried Psidium guajava and Azadirachta indica leaf extracts

\begin{tabular}{|l|l|l|l|l|l|l|}
\hline Particulars & \multicolumn{2}{|l|}{ Aqueous extract } & $\begin{array}{l}\text { Aqueous } \\
\text { extract }\end{array}$ & methanolic & Acetone extract \\
\hline & $\begin{array}{l}\text { Psidium } \\
\text { guajava }\end{array}$ & $\begin{array}{l}\text { Azadirachta } \\
\text { indica }\end{array}$ & $\begin{array}{l}\text { Psidium } \\
\text { guajava }\end{array}$ & $\begin{array}{l}\text { Azadirachta } \\
\text { indica }\end{array}$ & $\begin{array}{l}\text { Psidium } \\
\text { guajava }\end{array}$ & $\begin{array}{l}\text { Azadirachta } \\
\text { indica }\end{array}$ \\
\hline Alkaloids & + & ++ & ++ & +++ & +++ & + \\
\hline Tannins & ++ & + & ++ & + & +++ & + \\
\hline Saponins & ++ & ++ & ++ & ++ & + & - \\
\hline Flavonoids & + & + & +++ & ++ & + & + \\
\hline Glycosides & + & + & ++ & ++ & + & + \\
\hline
\end{tabular}

Absent, + Less concentration, ++ Moderate concentration, +++ High concentration

The acetone extract of Psidium guajava shows the maximum concentration of alkaloids and tannins and very less concentration of flavanoids and glycosides. Aqueous extract mainly contains saponins and tannins in moderate concentration where as Aqueous methanolic extract contains highest concentration of flavonoids and moderate concentration of alkaloids, tannins, saponis and glycosides. Similar findings were observed by Ekeleme et al., (2017)

The present study results with the Aqueous methanolic extract of Azadirachta indica contains moderate amount of saponins, favonoids and glycosides. Alkaloids are present in highest concentration in aqueous methnolic extract whereas moderate 
concentration in aqueous extract and tannin is very less in all the studied extracts. The high percentage of compounds that were identified in the crude extract is chemically and biologically important. The results of Priyanka et al., (2017) suggested that the Azadirachta indica extracts contain different phytochemicals with anti-inflammatory, antidiabetic, antimicrobial, and antioxidant properties. Phytochemical analysis of guava leaf contains alkaloids, contains, plenty of phenolic compounds which inhibit the peroxidation reaction in the body and so it can be expected to prevent various chronic diseases like diabetes, cancer cardiovascular affections. Furthermore, decreasing of free radicals in the body by means that the polyphenols in the leaf of $P$. guajava can prevent atherosclerosis, cataract and also inhibits biological aging of the body and skin

Phenolic compounds are known as powerful chain breaking antioxidants, and are important in the quenching $f$ free radicals thereby contribute directly to antioxidative action (Aghraj et al., 2018). Phenolic hydroxyl groups are the hydrogen donors and can react with reactive oxygen species in a termination reaction, stabilize the free radical and prevent the generation of new radicals (Valentao et al., 2003).

A number of studies have shown that plant polyphenols can be used as antioxidants against diferent oxidative stress-induced diseases (Boo, 2019). Thus, antioxidant compounds such as plant polyphenols have been suggested that they may be used for the prevention and/or treatment of this disease. (Jin et al., 2018). Studies of Sahrawat et al., (2018) reported the antimicrobial efficacy of Azadirachta indica leaves due to presene of alkaloids, flavonoids and glycosides in aquamethanolic extract of both the studied herbal formulations. The protective effect of phytochemicals bearing antioxidant, anti- inflammatory, antimicrobial, properties against various ailments has been attributed by the presence of phytochemicals (Mastuura and Fett-Neto, 2015).

In conclusion the phytochemical and biochemical experiments performed during the current study confirm that the extracts of the plant are rich in chlorophyll and proline. Methanolic extracts showed the presence of some common phytochemicals like alkaloids, saponins, tannins, glycosides, flavonoids and reducing sugars. Traditionally used by many people as an alternative treatment for a variety of health ailments and skin irritations. Commonly reported plant species need to be tested and validated their active ingredients in order to recommend effective preparations and treatments.

\section{References}

Aghraz, A., Gonçalves, S., Rodríguez-Solana, R., Dra, L. A., Di Stefano, V., Dugo, G., Cicero, N., Larhsini, M., Markouk, $\mathrm{M}$ and Romano, A. 2018. Antioxidant activity and enzymes inhibitory properties of several extracts from two Moroccan Asteraceae species South African Journal of Botany 118: 58-64.

Arika, W.M., Abdirahman, Y.A., Mawia, M.A., Wambua, K.F and Nyamai, D.W. 2015. In Vivo Antidiabetic Activity of the Aqueous Leaf Extract of Croton macrostachyus in Alloxan Induced Diabetic Mice. Pharmceutica Analytica Acta. 6: 447-452.

Boo, Y.C. 2019. Can Plant Phenolic Compounds Protect the Skin from Airborne Particulate Matter? Antioxidants. 8: 379-84.

Bukar, B.B., Dayom, D.W and. Uguru, M.O. 2016. The Growing Economic Importance of Medicinal Plants and The Need For Developing Countries To Harness From it: A Mini Review. IOSR 
Journal Of Pharmacy. 6(5): 42-52.

Ekeleme, K., Tsaku, P., Nkene, I., Ufomadu, U., Abimiku, R., Oti, V and Sidi, M. 2017. Phytochemical analysis and antibacterial activity of Psidium guajava L. leaf extracts. GSC Biological and Pharmaceutical Sciences, 1(2): 13-19.

El-Hawary, S.S., El-Tantawy, M.E., Rabeh, M.A and Badr, W.K. 2013. Chemical composition and biological activities of essential oils of Azadirachta indica A. Juss, International Journal of Applied Research in Natural Products, 6: 33- 42.

Evans, W.C. 2009 Trease and Evans' Pharmacognosy Elsevier Health Sciences.

Harbone. 1999. Harbone (Ed.), Phytochemical Dictionary, Taylor and Francis, London, .

Harborne, A.J. 1998 Phytochemical Methods A Guide to Modern Techniques of Plant Analysis Springer Netherlands 302p

Husain, A., Almatroudi, R.A., Alrumaihi, F and Khan, A.A. 2020. Pharmacological and Therapeutic Potential of Neem (Azadirachta indica). Pharmacognosy Reviews. 12(24): 250-255

Hussain, N.S., Naeem, N. et al. 2018. The phytochemistry and medicinal value of Psidium guajava (guava). Clin Phytosci 4: 3249.

Jin, T., Song, Z., Weng, J and Fantus, I.G. 2018. Curcumin and other dietary polyphenols: Potential mechanisms of metabolic actions and therapy for diabetes and obesity. Am J Physiol Endocrinol Meta. 314(3):201-205

Li, H.B., Cheng, K-W., Wong, C-C., Fan, KW., Chen, F and Jiang, Y. 2007. Evaluation of antioxidant capacity and total phenolic content of different fractions of selected microalgae Food Chemistry 1023 771-776.

Matsuura, H.N and Fett-Neto, A.G. 2015. Plant Alkaloids: Main Features,
Toxicity, and Mechanisms of Action. Plant Toxins. 2:1-15.

Oyenihi, A.B., Smith, C. 2019. Are polyphenol antioxidants at the root of medicinal plant anti-cancer success? J. Ethnopharmacol. 229: 54-72.

Padal, S.B., Sandhya, B., Chandrasekhar, P and Vijayakumar, Y. 2013. Folklore treatment of skin diseases by the tribes of G. Madugula Mandalam, Visakhapatnam District, Andhra Pradesh, India. J Environ Sci Toxicol Food Technol; 4: 26-29.

Raina, H., Soni, G., Jauhari, N., Sharma, N and Bharadvaja, N. 2014. Phytochemical importance of medicinal plants as potential sources of anticancer agents. Turk J Bot 38: 1027-1035

Ramadass, N and Subramanian N. 2018. Study of phytochemical screening of neem (Azadirachta indica). International Journal of Zoology Studies. 3(1): 209-212

Romila, Y., Mazumder, P.B and Choudhury, M.D. 2010 A review on antidiabetic plants used by the people of Manipur charactirized by hypoglycemic activity. Journal of Science \& Technology: Biological and Environmental Sciences 6: 167-175.

Romila, Y., Mazumder, P.B and Choudhurym, M.D. 2010. A review on antidiabetic plants used by the people of Manipur characterized by hypoglycemic activity. Journal of Science \& Technology: Biological and Environmental Sciences 6: 167-175.

Sahrawat, A., Sharma, J., Rahul, S.N., Tiwari, S., Joshi, M.D., Pundhir, A., Kumar, R et al., 2018. Phytochemical analysis and Antibacterial properties of Azadirachta indica (Neem) leaves extract against E.coli. Journal of Pharmacognosy and Phytochemistry 2018; 7(4): 1368-1371.

Valentao, P., Fernandes, E., Carvalho, F., Andrade, P.B., Seabra, R.M and 
Bastos, M.L 2003. Hydroxyl radical and hypochlorous acid scavenging activity of small centaury (Centaurium erythraea) infusion. A comparative study with green tea (Camellia sinensis). Phytomedicine. 10: 517- 522.

\section{How to cite this article:}

Chandnani, Y., M. Roy, S. Roy, B. Roopali and Dutta, G. K. 2020. Phytochemical Screening of Leaf Extracts of Azadirachta indica and Psidium guajava. Int.J.Curr.Microbiol.App.Sci. 9(09): 2852-2857. doi: https://doi.org/10.20546/ijcmas.2020.909.352 